\title{
Summer mean daily air temperature extremes in Central Spitsbergen
}

\author{
Ewa Bednorz • Leszek Kolendowicz
}

Received: 13 July 2012 / Accepted: 12 November 2012 / Published online: 29 November 2012

(C) The Author(s) 2012. This article is published with open access at Springerlink.com

\begin{abstract}
Summer mean daily temperature extremes in Svalbard Lufthavn (Central Spitsbergen) in the period 1975-2010 and daily pressure patterns and directions of air circulation conducive to their occurrence were analyzed. Positive (negative) extremes of daily mean temperatures in the summer were determined as higher (lower) than or equal to the value of the 90th (10th) percentile. The annual number of selected days shows a great year-to-year variability, although the annual number of extremely low mean daily temperature $\left(\leq 1.3^{\circ} \mathrm{C}\right)$ was decreasing in the $1976-2010$ period, with a rate of about 4 days per decade. At the same time, the number of days with extremely high mean daily temperatures $\left(\leq 8.2^{\circ} \mathrm{C}\right)$ was increasing with a rate of about 2 days per decade. The summer pressure patterns and the air circulation conditions have an impact on the occurrence of the air mean daily temperature extremes. Namely, anticyclones spreading east to the Svalbard Archipelago, accompanied by the Icelandic Low, cause the air inflow from the southerly direction and positive mean daily temperature extremes. A cyclonal system spreading east or southeast towards the archipelago, together with a high-pressure ridge over the North Atlantic, indicates the northern air flow and negative mean daily temperature extremes in summer. The results obtained in this study prove that the summer air temperature in the Atlantic region of the Arctic is partly controlled by air circulation, and despite the intensity and stability of the summer cyclones and anticyclones being weaker than in the winter, their position strongly determines the occurrence of mean daily temperature extremes in the summer.
\end{abstract}

E. Bednorz $(\varangle) \cdot$ L. Kolendowicz

Institute of Physical Geography and Environmental Planning,

Adam Mickiewicz University, ul. Dzięgielowa 27,

61-680 Poznań, Poland

e-mail: ewabedno@amu.edu.pl

\section{Introduction}

The annual patterns and the monthly records of the surface air temperature in the northern polar climates significantly differ from year to year. This is mostly because of the limited inflow of solar irradiation and a dominant impact of air circulation on the polar climate. The intense cyclonic activity in the Arctic and, in consequence, the quick exchange of air masses, originating from the north and from the south, cause great variations in the weather and temperature conditions (Steffensen 1982; Nordli 1990; Serreze et al. 1993; Førland et al. 1997; Zhang et al. 2004; Marsz and Styszyńska 2007; Rachlewicz and Styszyńska 2007). The impact of atmospheric circulation resulting from pressure patterns on the climate has been described in several studies concerning the Arctic (e.g., Serreze and Barry 1988; Wielbińska and Skrzypczak 1988; Serreze et al. 1993; Przybylak 1996, 2000; Hanssen-Bauer and Forland 1998; Niedźwiedź 2003, 2006; Zhang et al. 2004; Rogers et al. 2005; Maciejowski and Michniewski 2007). Most of the authors put an emphasis on the cyclonic activity during the cold season, which is characterized by the most dynamic changes of pressure patterns and weather conditions (Bednorz 2011).

The short period of polar summer, usually equal to the duration of a polar day, is the most stable season in terms of thermal conditions. It is also the only season when a reasonable inflow of solar irradiation comes to the ground, becoming a dominant factor affecting temperature increase. However, summer baric centers, although they are not as intensive and predominant as the winter ones, also influence the weather, mainly the air temperature and humidity.

The aim of the study is to detect summer mean daily temperature extremes in Spitsbergen and to recognize daily pressure patterns and directions of air circulation conducive to their occurrence. Considering the growing interest in the 
climate changes in Polar Regions, which are most vulnerable to current warming trends, any contribution to the discussion on the temperature in these regions and its circulation feedback seems to be essential.

\section{Area, data, and methods}

The island of Spitsbergen belonging to the Svalbard Archipelago is a part of the Euro-Atlantic sector of the Arctic. The island is surrounded by cold waters of the Arctic Sea in the north, the Barents Sea in the southeast, and the Greenland Sea in the southwest, which is warmed by the West Spitsbergen Current, a branch of the North Atlantic stream.

In this study, data from the Svalbard Lufthavn station $\left(78.25^{\circ} \mathrm{N}, 15.46^{\circ} \mathrm{E}, 2\right.$ ma.s.l.), typical of the central part of the island, were used. The station is located at the inner end of Adventfjorden, a southerly branch of Isfjorden, which is cut deeply from the west into the land (Nordli 1990) (Fig. 1). Therefore, Svalbard Lufthavn has more continental climate than other meteorological stations in the island, which are located mostly on the western shore. Daily mean surface air temperature data for the years 1976-2010 were collected from the Norwegian Meteorological Institute, available at the eKlima web portal. Additionally, the daily mean cloudiness was derived from the same source. Investigating the homogeneity of a time series is often very difficult in the Arctic due to the lack of neighboring stations (Nordli 1990). In the case of Svalbard Lufthavn, no changes in the location of the station took place in the studied period and the series was controlled and considered as homogenous (Førland et al. 1997; Nordli et al. 2000).

A significant feature of polar climate is a long and cold winter and a short summer with daily mean temperature exceeding $0{ }^{\circ} \mathrm{C}$. In some studies concerning the Arctic (Baranowski 1968; Kwaśniewska and Pereyma 2004), a period with daily mean temperature above $2.5{ }^{\circ} \mathrm{C}$ is considered thermal summer. Keeping this in mind, the months from June to August, which are characterized by mean temperature above $2.5{ }^{\circ} \mathrm{C}$, were taken into consideration in this study.

Summer extreme daily mean temperatures were determined, according to the Intergovernmental Panel on Climate Change (IPCC) rules, as occurring with a frequency lower than or equal to $10 \%$ (IPCC Fourth Assessment Report 2007; Ustrnul and Czekierda 2009).

Relating the occurrence of mean daily temperature extremes to synoptic conditions, the "environment to circulation" approach was applied. In this method, the circulation classification is carried along specific environment-based criteria set for a particular environmental phenomenon, i.e., mean daily temperature extremes in this case (Yarnal 1993; Yarnal et al. 2001; Dayan et al. 2012). In order to recognize pressure patterns and circulation conditions, which are favorable for positive and negative thermal extremes, the sea level pressure (SLP) daily data for the area shown in Fig. 1 were used. They were obtained from the National Centers for Environmental Prediction (NCEP)/ National Center for Atmospheric Research (NCAR) reanalysis data (Kalnay et al. 1996).

Firstly, the correlation coefficients between the daily mean surface temperatures in Svalbard Lufthavn and the daily values of SLP in the grid points in the area $60-90^{\circ} \mathrm{N}$ latitude by $60^{\circ} \mathrm{W}-80^{\circ} \mathrm{E}$ longitude were calculated and mapped. Furthermore, composite maps of the SLP means as well as SLP anomaly maps were constructed separately for the days with the positive and negative extremes of the mean daily temperature in the summer. Anomalies were computed as differences between composite values and summer means. Additionally, the mean daily air temperature at $850 \mathrm{hPa}$ isobaric level (T850) was taken into consideration (data derived from NCEP/NCAR reanalysis data; Kalnay et al. 1996), and temperature anomalies for defined situations were computed and mapped.

Furthermore, on the basis of the daily patterns of SLP, different circulation types were distinguished separately for
Fig. 1 Area under the study. Location of Svalbard Lufthavn station indicated with an arrow

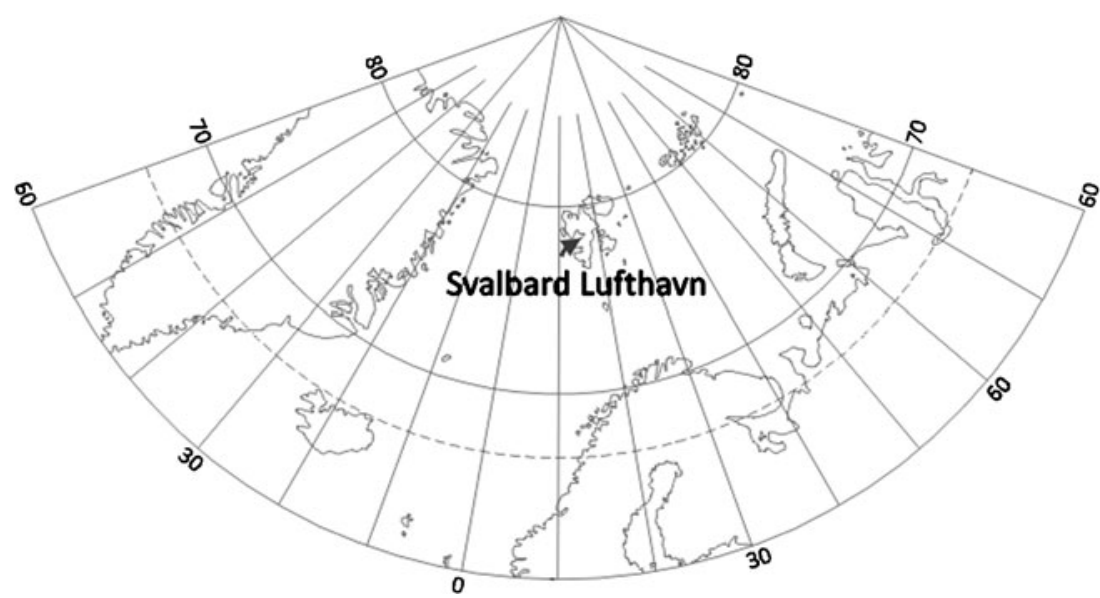


Table 1 Mean temperature and its standard deviation (in degrees Celsius) in Svalbard Lufthavn (1976-2010)

\begin{tabular}{lcccccccccccc}
\hline & January & February & March & April & May & June & July & August & September & October & November & December \\
Mean & -13.4 & -14.0 & -13.6 & -10.5 & -3.2 & 2.7 & 6.3 & 5.3 & 1.0 & -4.9 & -8.5 & -11.3 \\
$\begin{array}{c}\text { Monthly } \\
\text { standard } \\
\text { deviation }\end{array}$ & 4.9 & 4.2 & 4.1 & 3.8 & 1.8 & 1.2 & 0.9 & 1.0 & 1.6 & 2.0 & 3.7 & 4.6 \\
$\begin{array}{c}\text { Daily standard } \\
\text { deviation }\end{array}$ & 8.2 & 8.5 & 8.3 & 6.5 & 4.1 & 2.5 & 2.2 & 2.2 & 3.3 & 4.9 & 6.3 & 7.7 \\
\hline
\end{tabular}

the days with positive and negative summer mean daily temperature extremes, using the Ward's (1963) minimum variance method. This is a hierarchical clustering technique most frequently used for climatic classification (Kalkstein et al. 1987) for identifying the atmospheric circulation patterns associated with the occurrence of specific weather phenomena (e.g., Birkeland and Mock 1996; Esteban et al. 2005; Bednorz 2011). In the case of this study, the clustered objects were the days with the extremes of mean daily summer temperature (separately positive and negative), and the clustering was based on the daily SLP data.

The main idea of the clustering of data objects (days in this case) is the idea of distance. Clusters should consist of objects separated by small distances, relative to the distance between clusters. The commonly used distance measure in cluster analysis is the Euclidean distance in the multidimensional space of the data vectors. Ward's minimum variance method assumes that the pair of clusters will result in the minimum sum of squared distances between the objects and the centroids of their respective groups summed over the resulting groups (Wilks 1995).

\section{Results}

The mean annual course of the air surface temperature in Svalbard Lufthavn for the period (1976-2010) shows a long and cold period of polar winter (December-March) with the steady mean temperature well below $-10{ }^{\circ} \mathrm{C}$ (Table 1 ; Fig. 2). The minimum is reached towards the end of the polar night (February, $-14.0^{\circ} \mathrm{C}$ ), and afterwards, with the start of the polar day, i.e., as of April, temperature increases rapidly and reaches $2.7^{\circ} \mathrm{C}$ in June. The summer maximum $\left(6.3^{\circ} \mathrm{C}\right)$ falls on July. A positive mean monthly temperature prevails until September $\left(1.0{ }^{\circ} \mathrm{C}\right)$, and afterwards, it decreases quickly until December. A great variability in the winter season is a typical feature of the annual course of the air surface temperature in Spitsbergen and in the Polar Regions in general. Values of the mean monthly temperature change from year to year (standard deviation up to $4.9^{\circ} \mathrm{C}$ in January) as well as values of daily mean temperature, which varies from day to day (standard deviation exceeds $8.0^{\circ} \mathrm{C}$ ). The temperature of the summer months is much less variable, with the standard deviation for mean monthly values close to $1.0^{\circ} \mathrm{C}$ and ranging from 2.2 to $2.5^{\circ} \mathrm{C}$ for mean daily values.

The mean summer (June-August) temperatures in Svalbard Lufthavn show a moderate year-to-year variability and they ranged from $3.3{ }^{\circ} \mathrm{C}$ in 1982 to $6.4{ }^{\circ} \mathrm{C}$ in 2007 (Fig. 3). The linear trend of changes is positive and statistically significant $(p=0.01)$. Mean summer temperature is increasing with a rate of $0.5^{\circ} \mathrm{C} / 10$ years.

Positive (negative) extremes of daily mean temperatures in the summer were determined as higher (lower) than or equal to the value of the 90th (10th) percentile, namely, $\geq 8.2{ }^{\circ} \mathrm{C}\left(\leq 1.3{ }^{\circ} \mathrm{C}\right)$. The total number of days with both positive and negative extremes selected from 35 years exceeds 300 and the annual number of selected days shows a great year-to-year variability (Fig. 4), although a clear tendency can be seen in the trend of the annual number of
Fig. 2 Box plot graph for the annual course of the air temperature with standard deviation (box) and maximum/ minimum monthly means (whiskers) for the period 1976-2010 in Svalbard Lufthavn station

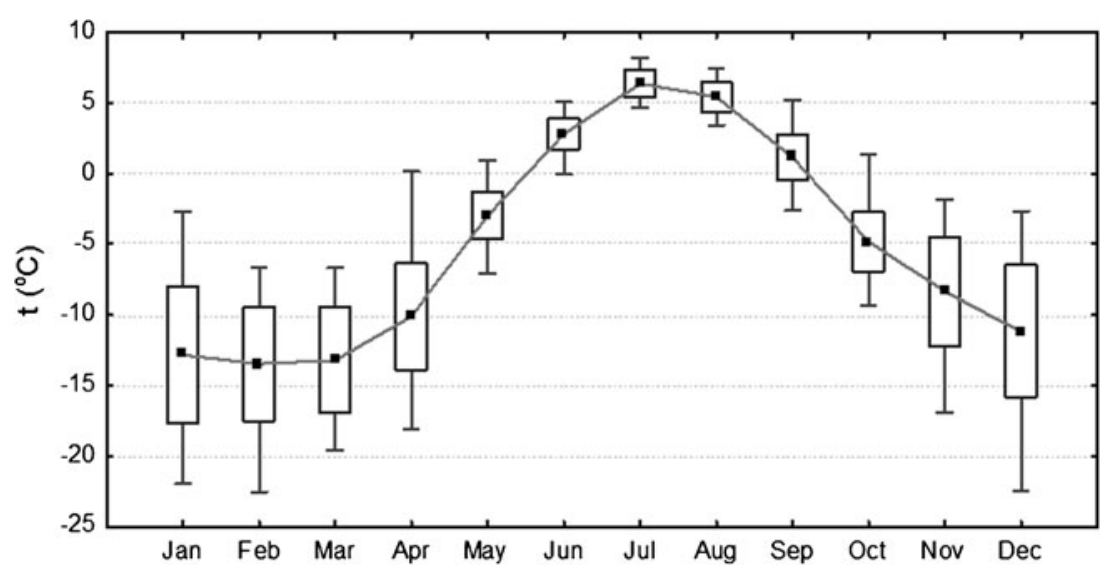


Fig. 3 Multiannual course of summer (June-August) mean air temperature in Svalbard Lufthavn station with trend line and equation

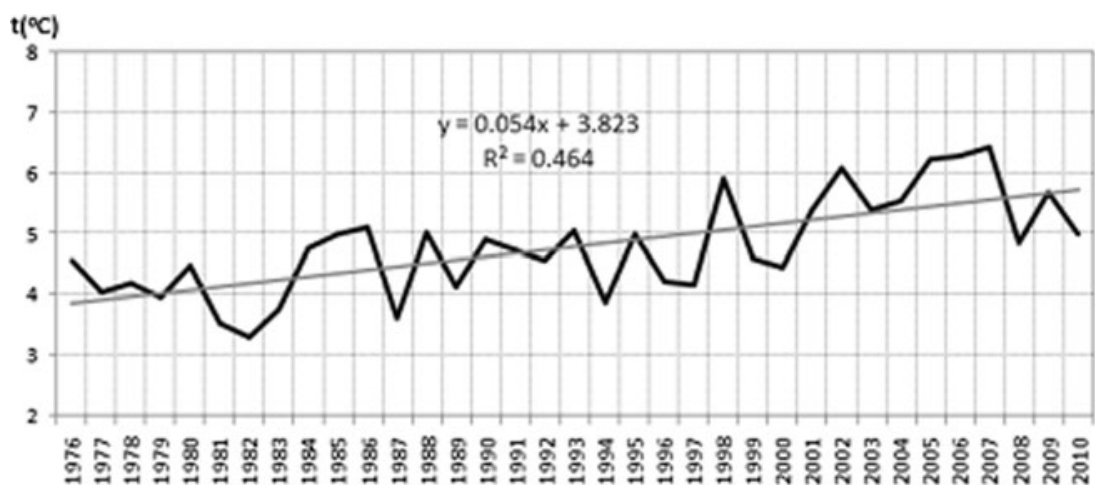

extremely low mean daily temperature $\left(\leq 1.3{ }^{\circ} \mathrm{C}\right)$. It was decreasing in the 1976-2010 period, with a rate of about 4 days per decade. At the same time, the number of days with extremely high mean daily temperatures $\left(\leq 8.2^{\circ} \mathrm{C}\right)$ was increasing with a rate of about 2 days per decade (both trends statistically significant at $p=0.01$ ).

Atmospheric circulation has a great impact on developing the field of air temperature and on the occurrence of temperature extremes in the polar climates. It becomes a particularly important factor during the polar night, where there is no solar irradiation and atmospheric and oceanic circulation is the only way of heat transfer. Mean winter pressure pattern over the Euro-Atlantic sector of the Arctic is characterized by a great pressure gradient between distinct baric centers, such as Icelandic Low, Greenland High, and anticyclone over the Eurasian continent (Fig. 5a). Correlation coefficients between the daily mean surface temperatures in Svalbard Lufthavn and the daily values of SLP computed for winter months prove a strong relationship between the pressure field and temperature on Spitsbergen Island. Two main "centers of action" can be indicated (Fig. 5c). A lowerthan-normal pressure along the east coast of Greenland (particularly over Fram Strait) is related to higher-thannormal mean daily temperatures over the Svalbard Archipelago (correlation coefficient $<-0.6$ ). When active cyclogenesis takes place along the northern coast of Greenland, the cyclones traverse just west of Spitsbergen, with a warm sector over the archipelago. On the other hand, lower-thannormal pressure over the south Barents Sea is related to lower-than-normal mean daily temperatures over the Svalbard Archipelago (correlation coefficient $>0.5$ ). Cyclones over the Barents Sea indicate airflow from the north and northeast, bringing cold Arctic air over the entire North Atlantic.

The mean SLP over the Arctic in summer (July-August) differs distinctly from the winter one, i.e., it is much less diversified and the gradient of the pressure field is very small (Fig. 5b). Also, the influence of pressure patterns on temperature in Svalbard Lufthavn is weaker. Correlation coefficients between the daily mean surface temperatures in Svalbard Lufthavn and the daily values of SLP in grid points computed for the summer months range from 0.33 to -0.26 . This time, the mean area of strong influence spreads east to the Svalbard Archipelago. A lower-thannormal pressure over the Franz Josef Land, meaning a cyclonal system located there, causes a decrease in the air temperature over the Spitsbergen Island. A secondary center of positive correlation spreads north to Iceland. Cyclonal activity in this area results in a higher-thannormal air temperature in Svalbard Lufthavn (Fig. 5d).

Although weaker than in winter, the summer SLP patterns and circulation conditions still have an impact on developing the field of the air temperature in the Arctic. At a composite contour map of SLP constructed for the days with positive mean daily temperature extremes in Svalbard Lufthavn, a distinct anticyclone spreads east to the archipelago (Fig. 6a). This anticyclone is the center of strongest positive SLP anomalies, exceeding $5 \mathrm{hPa}$ over the Franz
Fig. 4 Multiannual course of the number of days with the positive (dark gray) and negative (light gray) summer air temperature extremes in Svalbard Lufthavn station with trend lines and equations

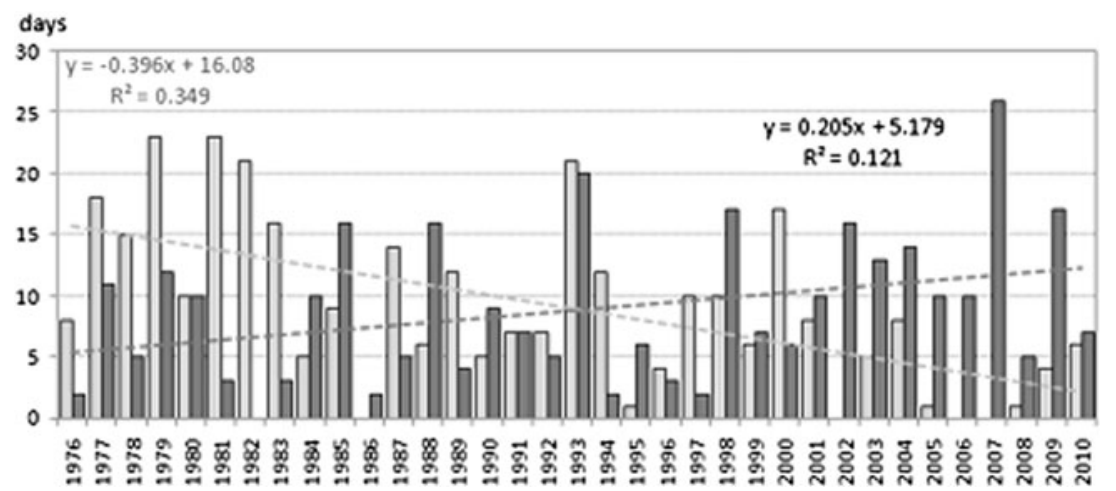



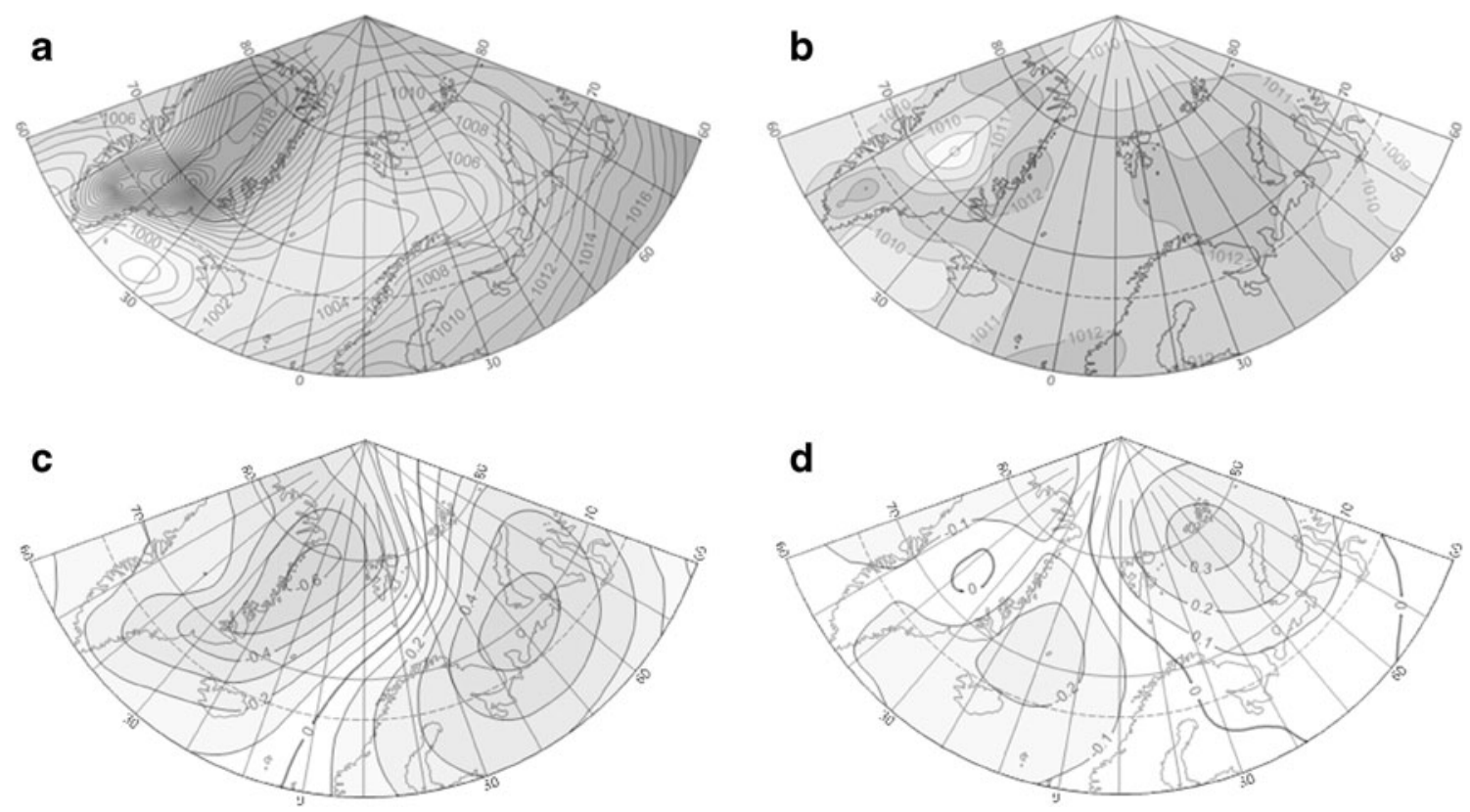

Fig. 5 Mean SLP in hectopascals (a winter, $\mathbf{b}$ summer) and the field of correlation coefficient between the daily mean air temperature in Svalbard Lufthavn and daily mean SLP (c winter, $\mathbf{d}$ summer)

Josef Land (Fig. 6c). Positive SLP anomalies take over most of the studied area, while weak negative SLP anomalies (up to $-3 \mathrm{hPa}$ ) are detected only in the south-central part of it. Both composite and anomaly maps of SLP indicate a strong southeasterly flow over the North Atlantic and European part of the Arctic, which causes an increase in temperature over most of the studied area. Positive anomalies of the air temperature at the isobaric level of $850 \mathrm{hPa}$ reach $5{ }^{\circ} \mathrm{C}$ over Spitsbergen Island (Fig. 6e).

Quite different conditions accompany the negative mean daily temperature extremes. In the contour map of SLP constructed for the days with summer negative mean daily temperature extremes, a cyclonal system spreads east to the Barents Sea (Fig. 6b). It is an area of negative SLP anomalies, which means that active cyclogenesis takes place in this part of the Arctic (Fig 6d). At the same time, positive anomalies are detected over North Atlantic, with the highest in its western part (exceeding $3 \mathrm{hPa}$ ). Such SLP pattern indicates the northern and northwestern flow, which brings cold air from the center of the Arctic to the North Atlantic. These result in negative anomalies of the air mean daily temperature at the isobaric level of $850 \mathrm{hPa}$ spreading all over the studied area, reaching an extreme value of $-6{ }^{\circ} \mathrm{C}$ over the Svalbard Archipelago (Fig. 6f).

The SLP patterns presented in the composite and anomaly maps in Figs. 5 and 6 give only a general idea of the synoptic conditions during positive and negative temperature extremes. The daily SLP fields both in the group of positive extremes and in the group of negative extremes could differ distinctly between each other. Therefore, the clustering technique was applied to the normalized daily
SLP data in order to classify the circulation types causing the positive mean daily temperature extremes in Central Spitsbergen. The three most relevant groups were distinguished and composite maps of SLP, as well as anomaly maps of T850, for each group were constructed (Fig. 7). In types 1 and 3 high-pressure systems spread to the east of the analyzed area, both providing air inflow from the southerly direction. In type 1, the anticyclone center locates right over Novaya Zemlya, while the deep Icelandic Low spreads over its normal position. Such pressure pattern causes southern circulation in the entire Norwegian Arctic. In consequence, an increase in temperature is observed, exceeding $5{ }^{\circ} \mathrm{C}$ over the Svalbard Archipelago. In type 1, the total cloudiness, which determines the rate of sun irradiation, is slightly lower than the summer normal in the Svalbard Lufthavn station $(75.2 \%)$ and it amounts to $67.4 \%$. In type 3 , the anticyclone locates over the Franz Josef Land Archipelago (right east to Spitsbergen), while the North Atlantic cyclone moves to the east with its center over the Norwegian Sea. A strong pressure gradient between the abovementioned centers of action causes an intensive southeastern influx, which brings warm and relatively dry air masses over the North Atlantic. In consequence, the mean cloudiness in type 3 decreases much below the summer mean (57.6\%) and anomalies of T850 exceed $6{ }^{\circ} \mathrm{C}$ over the Svalbard Archipelago. Type 2 represents quite a distinct pressure pattern. High pressure encompasses the western part of the area of the study, while a low-pressure system builds up in the southeast. Astonishingly, this time, as a result of the layout of the SLP fields, the northern inflow accompanies the positive extremes of mean daily summer temperature. Weak T850 anomalies (up 

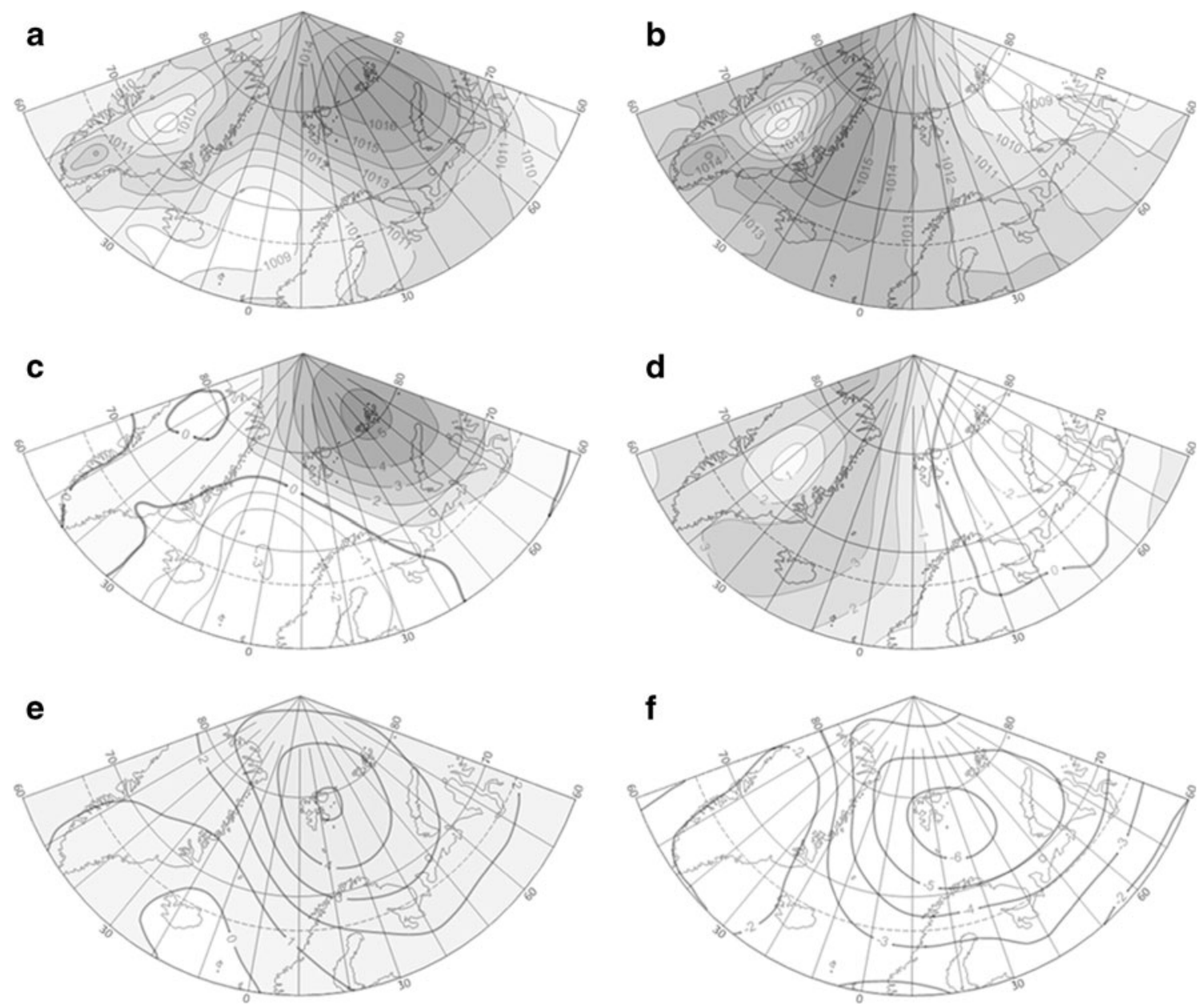

Fig. 6 Composite maps of mean SLP (in hectopascals) for the days with positive (a) and negative (b) temperature extremes in summer; anomaly maps of SLP (in hectopascals) for the days with positive (c)

to $2{ }^{\circ} \mathrm{C}$ over Svalbard Archipelago) and a relatively high surface air temperature in Svalbard Lufthavn $\left(9.3{ }^{\circ} \mathrm{C}\right)$ are due to the clear sky conditions, as the mean cloudiness in type 2 is the lowest among the three distinguished types $(44.1 \%)$ and it is by approximately $30 \%$ lower than the summer mean.

The same clustering procedure was applied to the normalized daily SLP data for the days with negative mean daily temperature extremes in order to classify the circulation types causing the negative mean daily temperature extremes in Central Spitsbergen. Composite maps of SLP and anomaly maps of T850 were constructed for the three distinguished groups (Fig. 8). The common feature of the pressure fields in all three types is a cyclone located in the eastern sector of the entire studied area. In type 1, the center of a not extensive and not too deep cyclone is located northeast of the Svalbard Archipelago. Counterclockwise air circulation around the center indicates northwestern inflow of air masses over Spitsbergen Island. Such inflow direction is strengthened by a high-pressure ridge over the

and negative (d) temperature extremes; anomaly maps of T850 (in degrees Celsius) for the days with positive (e) and negative (f) temperature extremes

North Atlantic. Negative anomalies of T850 spread over the entire area of the study and they exceed $-6{ }^{\circ} \mathrm{C}$ right over the Svalbard Archipelago. In type 2, the strongest negative anomalies of T850 (below $-8{ }^{\circ} \mathrm{C}$ ) appear over northeastern Europe and southern Barents Sea. They are caused by a cyclone located far into the southeast, which, together with a high-pressure ridge over North Atlantic, brings about northern air masses over the studied area. In the last type (3), the lowpressure system is formed over Scandinavia, while the highpressure area spreads on the opposite side of the Atlantic Ocean, along the eastern coast of Greenland. Cold air masses from the northeast flow along the northwestern ridge of the Scandinavian cyclone, causing the anomalies of T850 amounting to $-6{ }^{\circ} \mathrm{C}$ over the Svalbard Archipelago.

Circulation is definitely not the only factor bringing about summer thermal conditions in the Arctic. Nevertheless, the described location of the baric centers and consequently the direction of airflow differ distinctly in the positive and negative mean daily temperature extremes in Svalbard Lufthavn. 

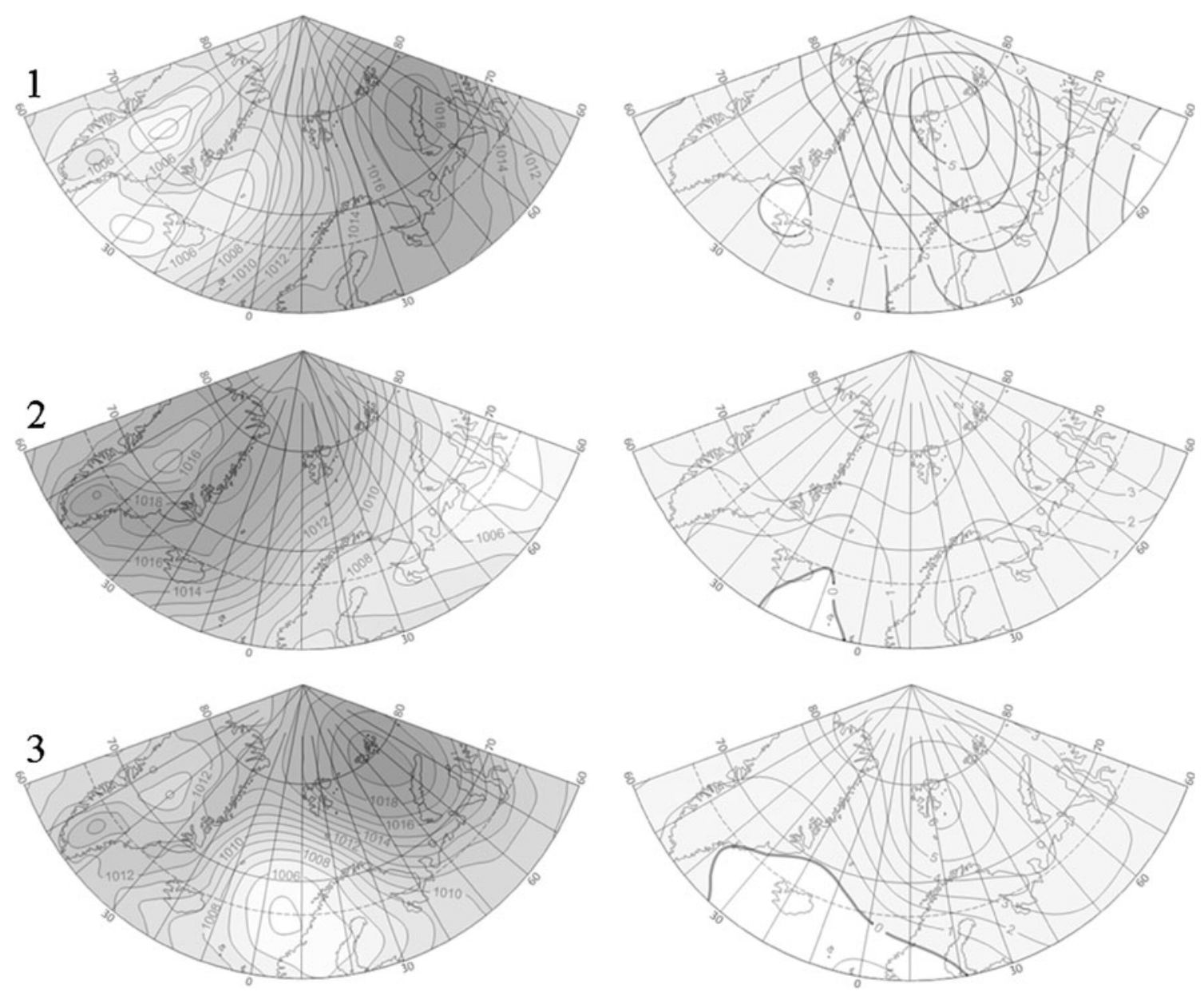

Fig. 7 Circulation types distinguished among the days with positive temperature extremes (SLP in hectopascals) in summer (left composite SLP, right anomalies of T850)

\section{Discussion and conclusions}

Changes in the occurrence of extreme temperatures may be considered one of the indicators of climatic changes in the Polar Regions. It makes them an important subject of climatologic studies, particularly at the age of dynamic climate changes (IPCC Fourth Assessment Report 2007). Although the rate of changes in the mean summer temperature in Svalbard Lufthavn during the recent 35 years is not very spectacular (about $0.5{ }^{\circ} \mathrm{C} / 10$ years) in comparison to the changes in the temperatures during the winter months $\left(1.65{ }^{\circ} \mathrm{C} / 10\right.$ years; Bednorz 2011), it is still statistically significant and it testifies to the warming in the Polar Regions. Similar results concerning changes of summer temperature in recent years were obtained for western Norway (Nordli et al. 2003). Simultaneous to the increase of the mean summer temperature, the annual number of days with positive summer mean daily temperature extremes was increasing with a rate of about 2 days per decade, while the annual number of days with negative summer extremes was decreasing with a rate of about 4 days per decade. Findings of both the present study concerning summer mean daily temperature extremes and the previous study by the same author concerning winter temperatures (Bednorz 2011) correspond to the increase in daily maximum and minimum temperatures in the second half of the twentieth century proved for the Fennoscandia and Nordic Sea regions (Tuomenvirta et al. 2000). They also confirm the contemporary warming in the Arctic, widely described in several studies (e.g., Brázdil 1988; Førland et al. 1997; Moritz et al. 2002; Comiso 2003; Polyakov et al. 2003; Przybylak 2000, 2002, 2003, 2007; Johannesen et al. 2004; Styszyńska 2005; Turner et al. 2006).

Although the fact of a temperature increase in the Arctic has been proven, the reasons for this process are considered to be very complex and they are still discussed. Air circulation is considered one of the main factors modifying temperature and, therefore, influencing the climate changes at high latitudes (e.g., Hanssen-Bauer and Forland 1998; Niedźwiedź 2003, 2006; Polyakov et al. 2003; Przybylak 2003). Serreze et al. (2011), investigating Arctic temperature anomalies in the last decade (2000-2009), have 

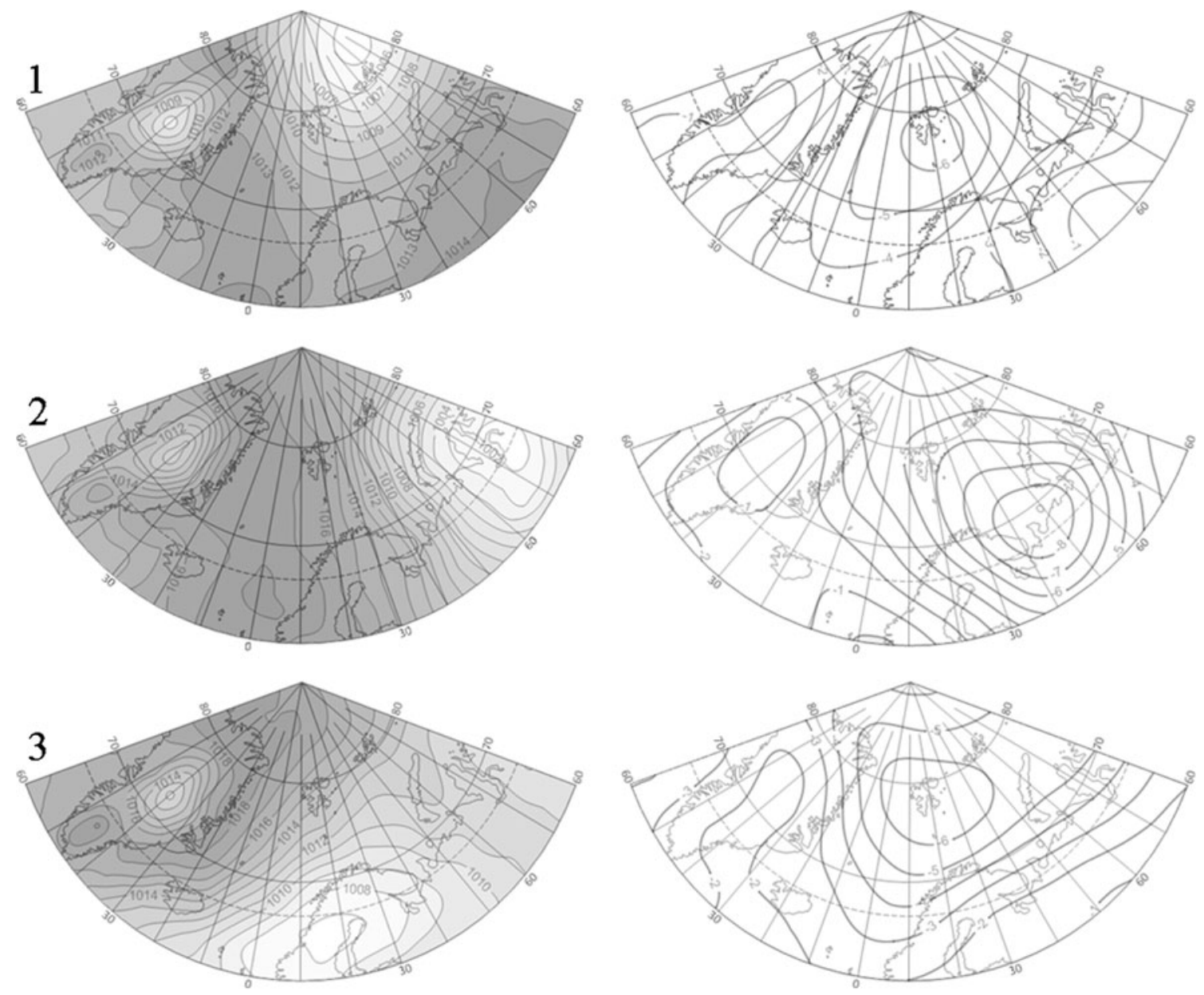

Fig. 8 Circulation types distinguished among the days with negative temperature extremes (SLP in hectopascals) in summer (left composite SLP, right anomalies of T850)

addressed three main factors: (1) a general background warming understood as a response to positive radiative forcing; (2) anomalies in atmospheric circulation; and (3) changes in surface characteristics, in particular, reduced sea ice extent and higher sea surface temperatures. However, they consider the second factor being apparent over the Atlantic side of the Arctic mainly in winter, while in other seasons, they have found the evidence much less clear. For instance, in summer, positive temperature anomalies may appear for different wind directions. It is not quite so for the extremes of the summer mean daily temperatures, as it was proven in this study. Although weaker than in the winter, the summer SLP patterns and circulation conditions still have an impact on developing the field of the air temperature in the Arctic. Namely, anticyclones spreading east to the Svalbard Archipelago, accompanied by the Icelandic Low, cause air inflow from the southerly direction and positive temperature extremes. On the other hand, a cyclonal system spreading east or southeast towards the archipelago, together with a high-pressure ridge over the North Atlantic, indicates the northern air flow and negative temperature extremes.
The results obtained in this study prove that the summer air temperature in the Atlantic region of the Arctic is partly controlled by air circulation, and despite the intensity and stability of the summer cyclones and anticyclones being weaker than in the winter, their position strongly determines the occurrence of temperature extremes in the summer.

Acknowledgments This work was partly supported by the Polish National Science Centre under grant number 2011/01/B/ST10/01923.

Open Access This article is distributed under the terms of the Creative Commons Attribution License which permits any use, distribution, and reproduction in any medium, provided the original author(s) and the source are credited.

\section{References}

Baranowski S (1968) Termika tundry peryglacjalnej SW Spitsbergen (Thermal conditions of the periglacial tundra SW Spitsbergen). Acta Universitatis Wratislaviensis 68, Studia Geograficzne 10:74 (in Polish) 
Bednorz E (2011) Occurrence of winter air temperature extremes in Central Spitsbergen. Theor Appl Clim 106(3-4):547-556

Birkeland KW, Mock CJ (1996) Atmospheric circulation patterns associated with heavy snowfall events, Bridger Bowl, Montana, U.S.A. Mt Res Dev 16:281-286

Brázdil R (1988) Variation of air temperature and atmospheric precipitation in the region of Svalbard. In: Brázdil R et al (eds) Results of investigations of the geographical research expedition Spitsbergen 1985. University J.E. Purkyne, Brno, pp 285-323

Comiso JC (2003) Warming trends in the Arctic from clear-sky satellite observations. J Climate 16(21):3498-3510

Dayan U, Tubia A, Levy I (2012) On the importance of synoptic classification methods with respect to environmental phenomena. Int J Climatol 32:681-694

Esteban P, Jones PD, Martin-Vide J, Mases M (2005) Atmospheric circulation patterns related to heavy snowfall days in Andorra, Pyrenees. Int J Climatol 25:319-329

Førland EJ, Hanssen-Bauer I, Nordli PØ (1997) Climate statistics and long term series of temperature and precipitation at Svalbard and Jan Mayen. DNMI Rapport 21/97, Norwegian Meteorological Institute, Oslo

Hanssen-Bauer I, Forland EJ (1998) Long-term trends in precipitation and temperature in the Norwegian Arctic: can there be explained by changes in atmospheric circulation patterns? Clim Res 10:143-153

IPCC Fourth Assessment Report (2007) Working Group I Report "The Physical Science Basis". Chapter 10. In: Global climate projections. Cambridge University Press, Cambridge

Johannesen OM, Bengtsson L, Miles MW, Kuzmina SI, Semenov VA, Alekseev GV, Nagurnyi AP, Zakharov VF, Bobylev LP, Pettersson LH, Hasselman K, Cattle HP (2004) Arctic climate change: observed and modeled temperature and sea-ice variability. Tellus 56A:328-341

Kalkstein LS, Tan G, Skindlov JA (1987) An evaluation of three Clustering procedures for use in synoptic climatological classification. J Clim Appl Meteorol 26:717-730

Kalnay E, Kanamitsu M, Kistler R, Collins W, Deaven D, Gandin L, Iredell M, Saha S, White G, Woollen J, Zhu Y, Leetmaa A, Reynolds R, Chelliah M, Ebisuzaki W, Higgins W, Janowiak J, Mo KC, Ropelewski C, Wang J, Jenne R, Joseph D (1996) The NMC/NCAR 40-year reanalysis project. Bull Amer Meteor Soc 77:437-471

Kwaśniewska E, Pereyma J (2004) Termiczne pory roku w Hornsundzie (SW Spitsbergen) (Thermal seasons in Hornsund (SW Spitsbergen)). Problemy Klimatologii Polarnej 14:157-168 (in Polish)

Maciejowski W, Michniewski A (2007) Variations in weather on the east and west coasts of South Spitsbergen, Svalbard. Pol Polar Res 28(2):123-136

Marsz A, and Styszyńska A (2007) Klimat rejonu Polskiej Stacji Polarnej w Hornsundzie - stan, zmiany i przyczyny (Climate of Polish polar station in Hornsund - the state, changes and reasons). Wydawnictwo Akademii Morskiej w Gdyni, Gdynia, p 376 (in Polish)

Moritz RE, Bitz CM, Steig EJ (2002) Dynamics of recent climate change in the Arctic. Science 297:1497-1502. doi:10.1126/science.1076522

Niedźwiedź T (2003) Współczesna zmienność cyrkulacji atmosfery, temperatury powietrza i opadów atmosferycznych na Spitsbergenie (Contemporary variability of atmospheric circulation, temperature and precipitation in Spitsbergen). Problemy Klimatologii Polarnej 13:79-92 (in Polish)

Niedźwiedź T (2006) Główne cechy cyrkulacji nad Spitsbergenem (XII.1950-IX.2006) (The main forms of atmospheric circulation above Spitsbergen. December 1950-September 2006). Problemy Klimatologii Polarnej 16:91-105 (in Polish)

Nordli PØ, Førland EJ, Niedźwiedź T (2000) Wind-chill temperature at Svalbard and Jan Mayen. DNMI Klima Rapport 07(00):1-47

Nordli PØ (1990) Temperature and precipitation series at Norwegian Arctic meteorological stations. DNMI KLIMA Rapport 40(90):1-14
Nordli PØ, Lie Ø, Nesje A, Dahl SO (2003) Spring-summer temperature reconstruction in western Norway 1734-2003: a data synthesis approach. Int J Climatol 23:1821-1841

Polyakov IV, Bekryaev RV, Alekseev GV, Bhatt US, Colony RL, Johnson MA, Maskshtas AP, Walsh D (2003) Variability and trends of air temperature and pressure in the maritime Arctic 1875-2000. J Climate 16(12):2067-2077

Przybylak R (1996) Zmienność temperatury powietrza i opadów atmosferycznych w okresie obserwacji instrumentalnych w Arktyce (Variability of air temperature and precipitation over the period of instrumental observations in the Arctic). Rozprawy, Uniwersytet Mikołaja Kopernika, Toruń

Przybylak R (2000) Temporal and spatial variation of surface air temperature over the period of instrumental observations in the Arctic. Int J Climatol 20(6):587-614

Przybylak R (2002) Variability of air temperature and atmospheric precipitation in the Arctic. Kluwer Academic, Dordrecht

Przybylak R (2003) The climate of the Arctic. Kluwer Academic, Dordrecht

Przybylak R (2007) Recent air-temperature changes in the Arctic. Ann Glaciol 46:316-324

Rachlewicz G, Styszyńska A (2007) Porównanie przebiegu temperatury powietrza w Petuniabukta i Svalbard-Lufthavn (Isfjord, Spitsbergen) w latach 2001-2003 (Comparison of the air temperature course in Petunia Bukta and Svalbard-Lufthavn (Isfjord, West Spitsbergen) in years 2001-2003). Problemy Klimatologii Polarnej 17:121-134 (in Polish)

Rogers JC, Yang L, Li L (2005) The role of Fram Strait winter cyclones on sea ice flux and on Spitsbergen air temperatures. Geophys Res Lett 32:L06709. doi:10.1029/2004GL022262, 4 pp

Serreze MC, Barrett AP, Cassano JJ (2011) Circulation and surface controls on the lower tropospheric air temperature field of the Arctic. J Geophys Res 116:D07104

Serreze MC, Barry RG (1988) Synoptic activity in the Arctic Basin, 1979-85. J Climate 1(12):1276-1295

Serreze MC, Box RG, Barry RG, Walsh JE (1993) Characteristics of Arctic synoptic activity. Meteorol Atmos Phys 51(3):147-164

Steffensen EL (1982) The climate at Norwegian Arctic stations. Det Norske Meteorologiske Institutt, Klima nr. 5, Oslo

Styszyńska A, (2005) Przyczyny i mechanizmy współczesnego (19822002) ocieplenia atlantyckiej Arktyki (Causes and mechanisms of present (1982-2002) warming of the Atlantic part of the Arctic). Wydawnictwo Uczelniane Akademii Morskiej w Gdyni (in Polish)

Tuomenvirta H, Alexandersson H, Drebs A, Frich P, Nordli PØ (2000) Trends in Nordic and Arctic temperature extremes and ranges. J Clim 13(3):977-990

Turner J, Overland JE, Walsh JE (2006) An Arctic and Antarctic perspective on recent climate change. Int J Climatol 27(3):277-293

Ustrnul Z, Czekierda D (2009) Atlas of extreme meteorological phenomena and synoptic situations in Poland. Instytut Meteorologii i Gospodarki Wodnej, Warsaw

Ward JH (1963) Hierarchical grouping to optimize an objective function. J Amer Stat Assoc 58:236-244

Wielbińska D, Skrzypczak E (1988) Mean air temperature at definite wind directions in Hornsund, Spitsbergen. Pol Polar Res 9 (1):105-119

Wilks DS (1995) Statistical methods in the atmospheric sciences: an introduction. International geophysics series, vol. 59. Academic, New York, 464 pp

Yarnal B (1993) Synoptic climatology in environmental analysis. Belhaven, London

Yarnal B, Comrie AC, Frakes B, Brown DP (2001) Developments and prospects in synoptic climatology. Int J Climatol 21:1923-1950

Zhang X, Walsh JE, Zhang J, Bhatt US, Ikeda M (2004) Climatology and inter-annual variability of Arctic cyclone activity: 19482002. J Climate 17:2300-2317 